\title{
EFFECT OF FARMYARD MANURE ON BARLEY PLANTS RESPONSE TO FOLIAR APPLICATIONS OF MICRONUTRIENTS AND SILICON IN SANDY SOIL IRRIGATED BY SALINE WATER
}

\author{
Manal F. Tantawy ${ }^{(1)}$, M. A. Ahmed ${ }^{(2)}$, B. Y. El-Koumey ${ }^{(2)}$, \\ E. A. Abou Hussien ${ }^{(2)}$ and Asmaa A. E. Emam ${ }^{(1)}$ \\ (1) Soils, Water and Environment Instiut. Res. Agric. Res. Center., Egypt. \\ (2) Soils. Sci., Dept. Fac. of Agric. Menofia Univ., Egypt.
}

Received: Nov. 6, 2018

Accepted: Dec. 23, 2018

\begin{abstract}
A pot experiment was carried out at the Experimental Farm, Faculty of Agriculture, Menoufia University, Shebin El-kom, Egypt during winter growth season of 2015/2016 to study the effect of foliar applications of silicon (Si) and micronutrients ( Fe, $\mathrm{Mn}$ and $\mathrm{Zn}$ ) individually and combined without and with farmyard manure ( FYM ) on barley plant (Hordeum Vulgare $L$ ) irrigated by saline water under sandy soil conditions. Surface soil sample $(0-20 \mathrm{~cm})$ representing sandy soil was collected from a private farm at $60 \mathrm{~km}$ North Cairo and far about one $\mathrm{km}$ east of Cairo - Alexandria Desert high away. Farmyard manure was added at a rate of $3 \%$ before sowing. Foliar application of silicon was carried as potassium silicate $\left(25 \% \mathrm{SiO}_{2}+10 \% \mathrm{~K}_{2} \mathrm{O}\right)$ " $\mathrm{F1}$ " where foliar solution of micronutrients of Fe, $\mathrm{Zn}$ and Mn mixture (12\%, 12\% and $14 \%$ respectively) " F2" in EDTA form. The final volume of foliar solutions was 400 liter /fed. Applications of F1, F2 and $F 1+F 2$ were carried out after 35 days of sowing.
\end{abstract}

The obtained data showed that individual and combined applications of F1 and F2 without and with FYM resulted in a significant increases of dry matter yields ( g/pot) of both roots and shoots of barley plants, where the highest values was resulted with the combined treatment of $F Y M+F 1+F 2$ followed by that resulted from the treatment of $F 2$ +F2. Also, the high contents and uptake of N, P, K, Fe, Mn, Zn and Si by both roots and shoots of barley plants were resulted from the treatment of F1+F2 with FYM. So, all relative changes ( $R C, \%$ ) values of macro- and micronutrients and silicon uptake by barley plants ( roots and shoots) at age 42 and 70 days were positive. From the obtained data may be concluded that, under sandy soil conditions using saline water for irrigation, organic manures and foliar applications of $\mathrm{Fe}, \mathrm{Mn}, \mathrm{Zn}$ and $\mathrm{Si}$ is very important to increase plant growth and decrease the harmful effect of salinity stress.

Key words : Foliar applications, Macro- and Micronutrients, Silicon, Farmyard manure, Sandy soil and Barley.

\section{INTRODUCTION}

Badran et al. (2000) and Gohar (2011) stated that, organic manures application as FYM, compost or biogas manure treatments significantly increased availability of $N, P$ and $K$. The increase effect of micronutrients on yield and crop performance has been reported by Rehm and Albert (2006). Micronutrients spraying led to increasing macro- and micronutrients uptake as a result of improving root growth which consequently led to greater absorbing surface Abdalla et al. (1992). They also find out that micronutrients foliar spraying (mixture of $\mathrm{Fe}, \mathrm{Mn}, \mathrm{Zn}$ ) can be used as a tool to increase wheat plant tolerance to salinity during early growth stages. Among different techniques, proper management of mineral nutrients plays a crucial role in increasing plant tolerance to salinity (Marschner, 1995). 
Mitani et al. (2005) found that $\mathrm{Si}$ is translocated in the form of monosilicic acid through the xylem in rice. It primarily accumulates in leaves because it is distributed with the transpiration stream . In dried plant parts the silica bodies are located in silica cells below the epidermis and in epidermal appendices (Dagmar et al., 2003). Being a dominant component of soil minerals the silicon has many important functions in environment. Although the silicon is not considered as an essential plant nutrient because most plants can be grown from seed to seed without its presence (Marschner, 1995), however, many plants can accumulate silicon concentrations higher than essential macronutrients (Epstein, 1999). Other studies have suggested the positive growth effects of silicon, including increased dry mass and yield, enhanced pollination (Korndörfer and Lepsch, 2001) and most commonly increased disease resistance (Gillman et al., 2003 and Rodrigues et al., 2004). It reduces micronutrient and metal toxicity (Britez et al., 2002) even if not taken up in appreciable amounts (Voogt and Sonnenfeld, 2001.).

Barley (Hordeum vulgare L.) is one of the most dependable cereal crops in harsh environment it is grown in semiarid areas as well as in cold, short- season areas. Local varieties and landraces of barley occupy nearly $80 \%$ of the cultivated areas in west Asia and north Africa and these should be collected before they are lose (Qadir et al., 2008). In other study, Walia et al. (2006) stated that barley is a salt, tolerant crop species with considerable economic importance in salinity affected arid and semiarid regions of the world. Barley is used mainly as a grain feed for livestock and as malt for the production of beer and malt enriched food products.
The main aims of this study are evaluate the effect of foliar applications of micronutrients ( $\mathrm{Fe}, \mathrm{Mn}$ and $\mathrm{Zn}$ ) and silicon ( $\mathrm{Si}$ ) without and with farmyard manure (FYM) application on plant growth and its tolerance for salinity of irrigation water under sandy soil conditions .

\section{MATERIALS AND METHODS} Soil Sampling .

- Surface soil sample (0-20) $\mathrm{cm}$ representing sandy soil was collected from a private farm at $60 \mathrm{~km}$ North Cairo and far about one $\mathrm{km}$ east of Cairo - Alexandria Desert high away. The collected sample was air dried, ground, good mixed and sieved through a $2 \mathrm{~mm}$ sieve. Some physical and chemical properties and the content of available nutrients and silicon of this soil were determined according to the international methods as described by Klute (1986), Cottenie et al. (1982) and Page et al. (1982), respectively. The obtained data were recorded in Table 1.

\section{Farmyard Manure (FYM).}

Air dried sample of FYM was obtained from the animal breeding farm, Faculty of Agriculture, Menoufia University, Shebin El- Kom, Menoufia Governorate, Egypt. The chemical analyses of FYM were carried out according to the methods described by Page et al. (1982). The obtained data were shown in Table 2.

\section{Irrigation Water.}

Water sample was collected from the well dug in the same private farm of soil sample. The collected water sample was analyzed for its chemical properties carried out according to the methods described by Cottenie et al. (1982). Data of analysis are shown in Table 3 . 
Table 1: Physical and chemical properties of the studied soil .

\begin{tabular}{|c|c|c|c|c|c|c|}
\hline \multicolumn{7}{|c|}{ a- Physical properties : } \\
\hline \multicolumn{6}{|c|}{ Particle size distribution (\%) } & WHC (\%) \\
\hline \multicolumn{2}{|c|}{ Sand } & \multirow{2}{*}{ Silt } & \multirow{2}{*}{\multicolumn{2}{|c|}{ Clay }} & \multirow{2}{*}{ Soil texture } & \multirow[b]{3}{*}{$21 \%$} \\
\hline Coarse & Fine & & & & & \\
\hline 56.7 & 31.8 & 8.0 & & 3.5 & Sandy & \\
\hline \multicolumn{7}{|c|}{ b-Chemical properties : } \\
\hline $\begin{array}{l}\text { pH }(1: 2.5) \\
\text { soil water } \\
\text { susp }\end{array}$ & $\begin{array}{c}E C^{\star} \\
\mathrm{dSm}^{-1}\end{array}$ & $\begin{array}{c}\mathrm{CaCO}_{3} \\
\mathrm{~g} \mathrm{~kg}^{-1}\end{array}$ & & $\begin{array}{c}\mathrm{OM} \\
\mathrm{g} \mathrm{kg}^{-1}\end{array}$ & $\underset{\mathrm{cmol}_{\mathrm{c}} \mathrm{kg}^{-1}}{\text { CEC }}$ & Esp \\
\hline 7.56 & 0.50 & 125.00 & & 1.200 & 3.02 & 1.80 \\
\hline \multicolumn{7}{|c|}{ c-The content of available nutrients and silicon $(\mathrm{mg} / \mathrm{kg}$ ) } \\
\hline $\mathbf{N}$ & $\mathbf{P}$ & K & Mn & $\mathrm{Fe}$ & $\mathbf{Z n}$ & Si \\
\hline 17.62 & 5.00 & 82.6 & 0.40 & 1.10 & 0.34 & 0.69 \\
\hline
\end{tabular}

*Soil paste extract

Table 2 : Some chemical properties of the used FYM.

\begin{tabular}{|c|c|}
\hline Properties and units & Values \\
\hline pH (1: 5) FYM: water susp. & 7.1 \\
\hline EC(1: 10) FYM: water susp ( $\left.\mathrm{dSm}^{-1}\right)$ & 8.5 \\
\hline OC $\quad(\%)$ & 19.12 \\
\hline OM $\quad(\%)$ & 32.6 \\
\hline Total N (\%) & 1.40 \\
\hline $\mathrm{C} / \mathrm{N}$ ratio & 13.66 \\
\hline Total P $\quad(\%)$ & 1.72 \\
\hline Total K (\%) & 2.11 \\
\hline \multicolumn{2}{|l|}{ The content of macronutrients $(\mathrm{mg} / \mathrm{kg}$ ) } \\
\hline $\mathbf{N}$ & 765 \\
\hline $\mathbf{P}$ & 430 \\
\hline K & 860 \\
\hline \multicolumn{2}{|c|}{ The content of micronutrients $\quad(\mathrm{mg} / \mathrm{kg})$} \\
\hline $\mathrm{Fe}$ & 120 \\
\hline $\mathrm{Zn}$ & 80 \\
\hline Mn & 102 \\
\hline The content of available Si (mg/kg) & Nd \\
\hline
\end{tabular}


Manal F. Tantawy, et al.,

Table 3: Analysis of the used irrigation water .

\begin{tabular}{|c|c|}
\hline Water properties and unit & Value \\
\hline $\mathrm{EC}\left(\mathrm{dSm}^{-1}\right)$ at $25^{\circ} \mathrm{C}$ & 6.00 \\
\hline Total soluble salts "TSS" $\mathrm{mgL}^{-1}$ & 3840 \\
\hline \multicolumn{2}{|l|}{ Soluble cations mmolc $\mathrm{L}^{-1}$} \\
\hline $\begin{array}{l}\mathrm{Ca}^{+2} \\
\mathrm{Mg}^{+2} \\
\mathrm{Na}^{+} \\
\mathrm{K}^{+}\end{array}$ & $\begin{array}{l}11.05 \\
10.03 \\
22.15 \\
0.52\end{array}$ \\
\hline \multicolumn{2}{|l|}{ Soluble anions $\quad\left(\mathrm{mmolc} \mathrm{L}^{-1}\right)$} \\
\hline $\begin{array}{l}\mathrm{CO}_{3}^{-2} \\
\mathrm{SO}_{4}^{-2} \\
\mathrm{HCO}_{3}^{-} \\
\mathrm{Cl}^{-}\end{array}$ & $\begin{array}{l}0.15 \\
3.35 \\
3.20 \\
37.05\end{array}$ \\
\hline SAR & 6.82 \\
\hline
\end{tabular}

\section{Green House Experiment.}

A pot experiment was conducted in the green house of Soil Science Department, Faculty of Agriculture, Shebin El-Kom, Menoufia University, Egypt at winter growing season of 2015 /2016 to study the individual and combined effects of foliar applications of $\mathrm{Si}$ " F1" and Fe, Mn and Zn mixture "F2" without and with FYM on barley plants (Hordeum vulgare $L$ ) growth in sandy soil irrigated by saline water. A 48 plastic pots with $25 \mathrm{~cm}$ inter diameter and $20 \mathrm{~cm}$ depth were used in this experiment. Five $\mathrm{kg}$ of the sieved sandy soil was put in each pot. The used pots were divided into two main groups ( 24 pots/ main group ) The soil in the pots of the first main group no received FYM but the pots of the second one treated with FYM at rate of $3 \%(150 \mathrm{~g} / \mathrm{pot})$. Before sowing, the treatment of FYM was carried out. At the same time all pots were fertilized with single super phosphate $\left(\begin{array}{lll}15.5 & \% & \mathrm{P}_{2} \mathrm{O}_{5}\end{array}\right)$ which added as a source of $P$ fertilization at the recommended dose of barley plant $(200 \mathrm{~kg} / \mathrm{fed}=1 \mathrm{~g} / \mathrm{pot})$.
Added FYM and $P$ fertilizer good mixed with the sandy soil. The pots of each main group were divided into 4 sub group ( 6 pot / sub group) representing the treatments of micronutrients ( $\mathrm{Fe}, \mathrm{Mn}$ and $\mathrm{Zn}$ mixture ) and silicon ( $\mathrm{Si}$ ) foliar applications . All foliar application were carried out at 35 days old of plants. Foliar application of silicon was carried as potassium silicate $\left(25 \% \mathrm{SiO}_{2}+10 \% \mathrm{~K}_{2} \mathrm{O}\right)$ "F1" where foliar solution of micronutrients of $\mathrm{Fe}, \mathrm{Zn}$ and $\mathrm{Mn}$ mixture (12\%, 12\% and $14 \%$ respectively) " F2" in EDTA form. The studied treatments were randomized design in six replicates. Each pot was sowing at the first day of November 2015-2016 by ten seeds of barley plants (Hordeum Vulgare L.) and moisted by tap water (first irrigation only) at $60 \%$ of soil water holding capacity . After ten days of sowing, the plants of each pot were thinned to five plants. After 21 days of sowing all pots were fertilized with ammonium nitrate ( $33 \%$ ) and potassium sulphate $\left(48 \% \mathrm{~K}_{2} \mathrm{O}\right)$ as $\mathrm{N}$ and $K$ fertilizers at rate of 150 and 100 
$\mathrm{kg} / \mathrm{fed}(0.75$ and $0.5 \mathrm{~g} / \mathrm{pot})$, respectively . Except the first irrigation, all pots were irrigated with the used saline water at $60 \%$ of soil water holding capacity. Irrigation process were repeated every three days representing. The used volumes of $F 1$ and $F 2$ were diluted before applications at 400 liter / fed.

After 42 days of sowing the plants were harvested separately from the first three replicates, while the plants of other three replicates were harvested after $\mathbf{7 0}$ days of sowing. Separately the harvested plants of each pot were air-dried, ovendried at $70^{\circ} \mathrm{C}$ for $48 \mathrm{hrs}$ weight as $\mathrm{g} /$ pot , ground and kept for chemical analysis

\section{Plant Analysis .}

A half $g$ of each oven dried plant sample was digested using $5 \mathrm{ml}$ of sulpheric and percholoric acids mixture at ratio of 3:1 according to Chapman and Pratt (1961). Plant content of N, P, K, Fe, $\mathrm{Mn}, \mathrm{Zn}$ and $\mathrm{Si}$ was determined in the plant digest using the methods described by Cottenie et al. (1982) .

\section{Statical Analysis .}

The obtained data were statistically analyzed using split spilt plot design with three replicates according to the computer program Costat statistical software. Mean values were compared with each other using the least Significant Deference (L.S.D) and Duncan. (Costat 6.311, Copyright (C) 1998-2005).

Relative Change (RC) of the obtained data of the studied treatment may be calculated using the following equation :

$$
R C=\left[\left(X_{S}-X_{C}\right) / X_{C}\right] \times 100
$$

$\mathrm{RC}=$ Relative change of the used treatment, XS = The value of the studied treatment and $X C=$ The value of the control treatment .

\section{RESULTS AND DISCUSSION}

1- Dry Matter Yield of Barley Plants .

The presented data in Table (4) showed that at the two growth periods. i.e 42 and 70 days there are a significant increases in the dry matter yield ( $/$ /pot) of barley plants ( shoot and root) as a result of individual and combined applications of FYM and both, F1 (Si) and F2 micronutrients ( $\mathrm{Fe}, \mathrm{Mn}$ and $\mathrm{Zn}$ ). At the two growth periods the barley plants received organic fertilizers in combination with foliar application of F1 and $F 2$ individually and combined have a high dry matter yield compared with the plants fertilized with their individual application. The found increases of barley plants dry matter yield show the enhanced effect of add FYM as organic fertilizers on plant growth.

The obtained data show that the values of dry matter yields ( $g$ / pot ) of barley plants ( shoots and roots) at the two growth yields periods were obtained with the treatment of F1 +F2 in combination with organic manure. The second high values of barley dry matter yield were found in the plants treated with $\mathrm{F} 1(\mathrm{~K}+\mathrm{Si})$ in combination with $\mathrm{FYM}$ at period 42 and 70 days. This trend may be cleared from the calculated RC (\%) values of both root and shoots of barley plants dry matter yield, where all RC values were positive and were more higher in comparison treatments of FYM and foliar applications of $F 1$ and F2 followed by the treatment of $F Y M+F 1$. These findings means that foliar applications of F1 and F2 individually and in combined have an enhance effect on plant growth which resulted from the effect of these applications on metabolic process and enzymes activities (Marschener, 1998). These results are in agreement with those of Liang et al. (2003), Zhu et al. (2004) and Rehm and Albert. (2006). On the other hand the dry 
Table (4) : Effect of foliar silicon "F1"and micronutrients"F2" on dry matter yield of barley plants and its relative change (\%) in sandy soil manured by farmyard manure at two growth periods .

$\sigma$

\begin{tabular}{|c|c|c|c|c|c|c|c|c|c|c|c|c|c|c|c|}
\hline \multirow{5}{*}{ } & \multicolumn{15}{|c|}{ Growth periods ( days) } \\
\hline & \multicolumn{5}{|c|}{40 days } & \multicolumn{10}{|c|}{70 days } \\
\hline & \multicolumn{2}{|c|}{$\begin{array}{l}\text { Without FYM } \\
\text { application } \\
\text { (a) }\end{array}$} & \multicolumn{3}{|c|}{$\begin{array}{l}\text { With FYM } \\
\text { application (b) }\end{array}$} & \multicolumn{5}{|c|}{$\begin{array}{l}\text { Root without and with FYM at } 70 \\
\text { days }\end{array}$} & \multicolumn{5}{|c|}{ Shoot without and with FYM at 70 days } \\
\hline & \multirow{2}{*}{ g/pot } & \multirow{2}{*}{$\begin{array}{l}\text { RC } \\
(\%)\end{array}$} & \multirow{2}{*}{ g/pot } & \multirow{2}{*}{$\begin{array}{l}\mathbf{R C} \\
(\%)\end{array}$} & \multirow{2}{*}{ 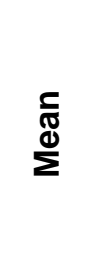 } & \multicolumn{2}{|c|}{$\begin{array}{c}\text { Without FYM } \\
\text { (a) }\end{array}$} & \multicolumn{2}{|c|}{$\begin{array}{l}\text { With FYM } \\
\text { (b) }\end{array}$} & \multirow{2}{*}{ 足 } & \multicolumn{2}{|c|}{$\begin{array}{c}\text { Without FYM } \\
\text { (a) }\end{array}$} & \multicolumn{2}{|c|}{$\begin{array}{l}\text { With FYM } \\
\text { (b) }\end{array}$} & \multirow{2}{*}{$\stackrel{\S}{\Perp}$} \\
\hline & & & & & & g/pot & $\begin{array}{l}\text { RC } \\
(\%)\end{array}$ & g/pot & $\begin{array}{l}\mathrm{RC} \\
(\%)\end{array}$ & & g/pot & $\begin{array}{l}\text { RC } \\
(\%)\end{array}$ & g/pot & $\begin{array}{l}\mathrm{RC} \\
\text { (\%) }\end{array}$ & \\
\hline Control & 2.60 & 0.0 & 5.90 & 0.0 & 4.25 & 2.70 & 0.0 & 3.90 & 0.0 & 3.30 & 6.3 & 0 & 8.6 & 0.0 & 7.45 \\
\hline F1 & 4.33 & 65.4 & 6.85 & 16.9 & 5.59 & 4.60 & 70.4 & 8.42 & 115.4 & 6.51 & 7.69 & 22.2 & 11.00 & 27.9 & 9.35 \\
\hline F2 & 4.25 & 65.4 & 6.81 & 15.4 & 5.53 & 4.50 & 66.7 & 8.38 & 115.9 & 6.44 & 7.65 & 22.2 & 10.95 & 27.9 & 9.30 \\
\hline \multirow[t]{2}{*}{$F 1+F 2$} & 4.38 & 69.2 & 6.87 & 16.9 & 5.63 & 4.95 & 85.2 & 8.49 & 117.9 & 6.72 & 7.72 & 22.2 & 11.15 & 30.2 & 9.44 \\
\hline & 3.89 & & 6.61 & & 5.25 & 4.19 & & 7.30 & & 5.74 & 7.34 & & 10.43 & & 8.88 \\
\hline $\begin{array}{l}\text { L.S.D at } 0.05 \text { level } \\
\text { Mineral (a) }\end{array}$ & \multicolumn{2}{|c|}{0.103} & & & & \multicolumn{2}{|c|}{0.0583} & & & & \multicolumn{2}{|c|}{0.166} & & & \\
\hline $\begin{array}{l}\text { L.S.D at } 0.05 \text { level } \\
\text { FYM (b) }\end{array}$ & & & \multicolumn{3}{|c|}{0.073} & & & \multicolumn{3}{|c|}{0.0412} & & & \multicolumn{3}{|c|}{0.117} \\
\hline
\end{tabular}


matter yield increases of barley plants dry matter yield as a result of FYM application attributed to its effect on soil properties and its content of available macro- and micronutrient as prementioned before that by Emam (2011) and El-Sanat (2018) .

\section{Barley Plants Content of Macronutrients ( N, P And K) .}

The data in Table (5) showe $N, P$ and $K$ concentration (\%) and uptake (mg/pot) by roots and shoots of barley plants grown in sandy soil irrigated by saline water at 42 and 70 days old in relation to the studied treatments. These data show that there are an increase of barley plants (shoots and roots) concentration and uptake of N, P and K with the treatments under study compared with the control treatment. In general with the same treatments of foliar applications, barley plants grown in the sandy soil received, FYM have a high content ( $\%$ and $\mathrm{mg} / \mathrm{pot}$ ) of $\mathrm{N}, \mathrm{P}$ and $\mathrm{K}$ compared with those found with the plants grown in the unmanured soil. These findings were observed for both roots and shoots at two growth periods. The found increases of barley plants content of $N, P$ and $K$ as a result of FYM application attributed to its content of nutrients and also its effect on these nutrients availability as a result of its influence on physical and chemical properties especially the decrease in both soil pH and the content of calcium carbonate (Emam, 2011, Abou Hussien et al., 2017 and El-Sanat 2018). Also, data in Table (5) show that FYM with all applications, the contents $(\%$ and $\mathrm{mg} /$ pot ) of $N, P$ and $K$ in both roots and shoots of barley plants at two growth periods were increased as a result of foliar application of silicon (F1) and micronutrients (F2) individually and incombined. The found increases of $\mathbf{N}$, $P$ and $K$ content in the plants sprayed by $F 1$ were higher than those resulted from F2 treatment. More $\mathrm{N}, \mathrm{P}$ and $\mathrm{K}$ content was found in the plants sprayed by $F 1$ and F2 together. Such increase may explained based on the enhanced effect of sprayed $\mathrm{Fe}, \mathrm{Mn}, \mathrm{Zn}$ and $\mathrm{Si}$ on plant growth, metabolic processes and enzymes activities (Marschener, 1998 ) . These results are in similar with those obtained by Abdalla et al. (1992) and Rehm and Albert( 2006). The found increases of $\mathrm{N}, \mathrm{P}$ and $\mathrm{K}$ uptake ( $\mathrm{mg} / \mathrm{pot}$ ) by both shoots and roots of barley plants at 42 and 70 plant age varied widely according to the studied treatment (Table, 5) .The rate of these variations may be cleared and defined from the calculated RC( \%) of these nutrients uptake compared with the control treatments as listed in Table 5 . These data show that all RC values of N, P and $K$ uptake by both roots and shoots of barley plants were positive. Without and with FYM application and according to RC values of $N, P$ and $K$, the foliar application take the order $\mathrm{F} 1+\mathrm{F} 2>\mathrm{F} 1>$ F2 > control. This order was found with roots and shoots of barley plants at plant age 42 and 70days. In general RC (\%) values of $N, P$ and $K$ uptake by plants grown in soil treated by FYM were higher than those calculated for the plants in the unmanured soil. The positive $R C$ values of $\mathrm{N}, \mathrm{P}$ and $\mathrm{K}$ uptake means that both individual and combined applications of FYM , micronutrient and silicon increased barley plants tolerance to salt stress resulted from using saline water in irrigation .

\section{Barley Plants Content of Micronutrients ( $\mathrm{Fe}, \mathrm{Mn}$ and $\mathrm{Zn}$ ).}

The presented data in Table 6 show $\mathrm{Fe}, \mathrm{Mn}$ and $\mathrm{Zn}$ concentration $(\mathrm{mg} / \mathrm{kg})$ and uptake ( $\mathrm{mg} /$ pot ) of barley plants (shoots and roots ) grown in sandy soil at ages 42 and 70 days affected by the individual and combined foliar applications of silicon (F1) and micronutrients (F2) without and with (FYM) applications . The 
Table 5 : Effect of the studied treatments on $\mathrm{N}, \mathrm{P}$ and $\mathrm{K}$ concentration (\%) and uptake (mg/pot) of barley plants ( roots and shoots) and relative changes "RC"(\%) of their uptake in sandy soil irrigated by saline water .

\begin{tabular}{|c|c|c|c|c|c|c|c|c|c|c|c|c|c|c|c|c|c|c|}
\hline \multirow{5}{*}{ 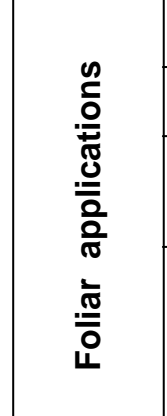 } & \multicolumn{18}{|c|}{ Growth period ( days ) } \\
\hline & \multicolumn{6}{|c|}{42 day } & \multicolumn{12}{|c|}{70 day } \\
\hline & \multirow{2}{*}{\multicolumn{2}{|c|}{$\begin{array}{c}\text { Without } \\
\text { FYM }\end{array}$}} & \multirow[b]{3}{*}{ ৩ণ } & \multirow{2}{*}{\multicolumn{2}{|c|}{ With FYM }} & \multirow[b]{3}{*}{ ৩ } & \multicolumn{6}{|c|}{ Without FYM } & \multicolumn{6}{|c|}{ With FYM } \\
\hline & & & & & & & \multicolumn{2}{|c|}{ Roots } & \multirow[b]{2}{*}{ ن } & \multicolumn{2}{|c|}{ shoots } & \multirow[b]{2}{*}{ U্口 } & \multicolumn{2}{|c|}{ Roots } & \multirow[b]{2}{*}{ ن ণ } & \multicolumn{2}{|c|}{ Shoots } & \multirow[b]{2}{*}{ ○ } \\
\hline & ๙ & $\frac{\text { 응 }}{\text { 을 }}$ & & ஓ & $\frac{\text { 음 }}{\text { 음 }}$ & & ๙ & $\frac{\text { 음 }}{\text { 을 }}$ & & อ & $\frac{\text { 응 }}{\text { 을 }}$ & & ஓ & $\frac{\text { 음 }}{\text { 을 }}$ & & ळ & $\frac{\text { 음 }}{\text { 음 }}$ & \\
\hline & \multicolumn{18}{|c|}{ Nitrogen ( N) } \\
\hline $\begin{array}{c}\text { Control } \\
\text { F1 } \\
\text { F2 } \\
\text { F1+F2 }\end{array}$ & $\begin{array}{l}0.36 \\
0.48 \\
0.72 \\
1.08\end{array}$ & \begin{tabular}{|c|}
9.4 \\
20.8 \\
30.6 \\
47.3
\end{tabular} & $\begin{array}{c}0.0 \\
122.1 \\
226.9 \\
405.4\end{array}$ & $\begin{array}{l}0.54 \\
1.02 \\
0.86 \\
1.08\end{array}$ & $\begin{array}{l}31.9 \\
69.9 \\
58.8 \\
74.2\end{array}$ & \begin{tabular}{|c|}
0.0 \\
119.3 \\
84.7 \\
132.9
\end{tabular} & $\begin{array}{l}0.60 \\
0.86 \\
0.80 \\
0.93\end{array}$ & \begin{tabular}{l|}
16.7 \\
39.1 \\
36.1 \\
46.0
\end{tabular} & \begin{tabular}{c|}
0.0 \\
133.8 \\
115.5 \\
175.0
\end{tabular} & $\begin{array}{l}1.32 \\
2.40 \\
2.31 \\
2.41\end{array}$ & \begin{tabular}{|c|}
83.2 \\
$184 . .6$ \\
176.7 \\
186.1
\end{tabular} & $\begin{array}{c}0.0 \\
121.9 \\
112.5 \\
123.7\end{array}$ & $\begin{array}{l}0.60 \\
0.91 \\
0.86 \\
0.95\end{array}$ & \begin{tabular}{|l|}
23.4 \\
76.6 \\
72.1 \\
80.7
\end{tabular} & \begin{tabular}{|c|}
0.0 \\
227.4 \\
208.0 \\
244.7
\end{tabular} & $\begin{array}{l}1.50 \\
2.75 \\
2.62 \\
2.98\end{array}$ & $\begin{array}{l}129.0 \\
302.5 \\
286.9 \\
332.3\end{array}$ & $\begin{array}{c}0.0 \\
134.5 \\
122.4 \\
157.6\end{array}$ \\
\hline Mean & 0.66 & 27.13 & & 0.88 & 58.7 & & 0.80 & 34.5 & & 2.11 & 148.7 & & 0.83 & 63.2 & & 2.46 & 262.7 & \\
\hline & \multicolumn{18}{|c|}{ Phosphorus ( P) } \\
\hline $\begin{array}{c}\text { Control } \\
\text { F1 } \\
\text { F2 } \\
\text { F1+F2 }\end{array}$ & $\begin{array}{l}0.26 \\
0.31 \\
0.30 \\
0.34\end{array}$ & \begin{tabular}{|c|}
6.8 \\
13.4 \\
12.8 \\
14.9
\end{tabular} & $\begin{array}{c}0.0 \\
98.6 \\
88.6 \\
120.3\end{array}$ & $\begin{array}{l}0.40 \\
0.48 \\
0.47 \\
0.51\end{array}$ & $\begin{array}{l}23.6 \\
32.9 \\
32.0 \\
35.0\end{array}$ & $\begin{array}{c}0.0 \\
39.3 \\
35.6 \\
48.5\end{array}$ & $\begin{array}{l}0.40 \\
0.43 \\
0.42 \\
0.45\end{array}$ & \begin{tabular}{|l|}
10.8 \\
19.8 \\
18.9 \\
22.3
\end{tabular} & $\begin{array}{c}0.0 \\
81.2 \\
75.4 \\
106.3\end{array}$ & $\begin{array}{l}0.72 \\
0.65 \\
0.64 \\
0.76\end{array}$ & \begin{tabular}{|l|}
45.4 \\
50.0 \\
49.0 \\
58.7
\end{tabular} & $\begin{array}{c}0.0 \\
10.2 \\
7.9 \\
29.3\end{array}$ & $\begin{array}{l}0.51 \\
0.60 \\
0.60 \\
0.63\end{array}$ & \begin{tabular}{|l|}
19.9 \\
50.5 \\
50.3 \\
53.5
\end{tabular} & \begin{tabular}{|c|}
0.0 \\
154.0 \\
152.8 \\
168.9
\end{tabular} & \begin{tabular}{|c|}
64.5 \\
104.5 \\
102.9 \\
111.5
\end{tabular} & \begin{tabular}{|c|}
0.0 \\
62.0 \\
59.6 \\
72.9
\end{tabular} & \\
\hline Mean & 0.30 & 11.96 & & 0.47 & 30.88 & & 0.43 & 17.94 & & 0.69 & 50.74 & & 0.59 & 43.54 & & 0.91 & 95.86 & \\
\hline & \multicolumn{18}{|c|}{ Potassium (K) } \\
\hline $\begin{array}{c}\text { Control } \\
\text { F1 } \\
\text { F2 } \\
\text { F1+F2 }\end{array}$ & $\begin{array}{l}1.05 \\
1.94 \\
1.88 \\
1.95\end{array}$ & \begin{tabular}{|l|}
27.3 \\
84.0 \\
79.9 \\
85.4
\end{tabular} & $\begin{array}{c}0.0 \\
207.7 \\
192.7 \\
212.9\end{array}$ & $\begin{array}{l}1.75 \\
2.37 \\
1.83 \\
2.37\end{array}$ & \begin{tabular}{|l|}
103.3 \\
162.3 \\
124.6 \\
162.8
\end{tabular} & $\begin{array}{c}0.0 \\
57.2 \\
20.7 \\
57.9\end{array}$ & $\begin{array}{l}1.76 \\
2.69 \\
1.98 \\
2.70\end{array}$ & \begin{tabular}{|c|}
47.5 \\
123.7 \\
89.1 \\
133.7 \\
\end{tabular} & $\begin{array}{c}0.0 \\
157.0 \\
87.5 \\
180.6\end{array}$ & $\begin{array}{l}1.78 \\
3.08 \\
2.50 \\
3.09\end{array}$ & $\begin{array}{l}112.1 \\
236.9 \\
191.3 \\
238.5\end{array}$ & \begin{tabular}{|c}
0.0 \\
110.7 \\
70.2 \\
112.2
\end{tabular} & $\begin{array}{l}1.75 \\
2.97 \\
2.45 \\
2.98\end{array}$ & $\begin{array}{c}68.3 \\
250.1 \\
205.3 \\
253.0\end{array}$ & $\begin{array}{c}0.0 \\
266.4 \\
200.8 \\
270.7\end{array}$ & $\begin{array}{l}2.62 \\
3.79 \\
3.39 \\
3.80\end{array}$ & \begin{tabular}{|l|}
225.3 \\
416.9 \\
371.2 \\
423.7
\end{tabular} & $\begin{array}{c}0.0 \\
85.0 \\
64.8 \\
88.1\end{array}$ \\
\hline Mean & 1.71 & 69.15 & & 2.08 & 138.26 & & 2.28 & 98.50 & & 2.61 & 194.70 & & 2.54 & 194.16 & & 3.40 & 359.28 & \\
\hline
\end{tabular}


Table 6: Effect of the studied treatments on Fe, Mn and $\mathrm{Zn}$ concentration $(\mathrm{mg} / \mathrm{kg}$ ) and uptake (mg/pot) of barley plants (roots and shoots) and relative changes "RC"(\%) of their uptake in sandy soil irrigated by saline water

\begin{tabular}{|c|c|c|c|c|c|c|c|c|c|c|c|c|c|c|c|c|c|c|}
\hline \multirow{5}{*}{ 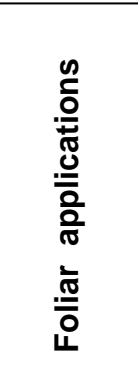 } & \multicolumn{18}{|c|}{ Growth period ( days ) } \\
\hline & \multicolumn{6}{|c|}{42 day } & \multicolumn{12}{|c|}{70 day } \\
\hline & \multirow{2}{*}{\multicolumn{2}{|c|}{ Without FYM }} & \multirow{3}{*}{ ن } & \multirow{2}{*}{\multicolumn{2}{|c|}{ With FYM }} & \multirow{3}{*}{ ن ঐ } & \multicolumn{6}{|c|}{ Without FYM } & \multicolumn{6}{|c|}{ With FYM } \\
\hline & & & & & & & \multicolumn{2}{|c|}{ Roots } & \multirow[b]{2}{*}{ ৩ ঐ } & \multicolumn{2}{|c|}{ shoots } & \multirow[b]{2}{*}{ પ } & \multicolumn{2}{|c|}{ Roots } & \multirow[b]{2}{*}{ ن } & \multicolumn{2}{|c|}{ Shoots } & \multirow[b]{2}{*}{ ن্ৰ } \\
\hline & 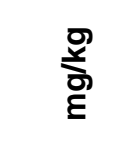 & $\begin{array}{l}\frac{+}{\circ} \\
\stackrel{2}{\circ} \\
\text { 을 }\end{array}$ & & 㝘 & $\begin{array}{l}\frac{\varpi}{\circ} \\
\frac{2}{\circ} \\
\text { E }\end{array}$ & & 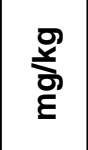 & $\begin{array}{l}\text { 을 } \\
\text { 을 }\end{array}$ & & 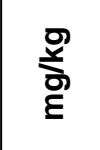 & $\frac{\text { 을 }}{\text { 을 }}$ & & 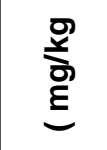 & $\begin{array}{l}\text { 응 } \\
\stackrel{2}{\circ} \\
\text { 을 }\end{array}$ & & 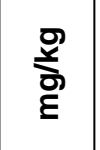 & $\frac{\text { 을 }}{\text { 을 }}$ & \\
\hline & \multicolumn{18}{|c|}{ Iron ( Fe ) } \\
\hline Control & 40.1 & 1042.9 & 0.0 & 47.1 & 2779.9 & 0.0 & 38.7 & 1044.9 & 0.0 & 36.5 & 2299.5 & 0.0 & 46.8 & 1825.2 & 0.0 & 45.5 & 3913.0 & 0.0 \\
\hline F1 & 42.5 & 1840.3 & 76.5 & 50.3 & 3445.6 & 23.9 & 40.7 & 1872.2 & 77.0 & 39.2 & 3014.5 & 30.9 & 49.1 & 4134.2 & 126.5 & 47.1 & 5181.0 & 32.5 \\
\hline F2 & 92.1 & 3915.5 & 275.5 & 96.8 & 6592.1 & 137.1 & 90.4 & 4068.04 & 290.0 & 87.5 & 6693.8 & 191.1 & 95.1 & 7969.4 & 336.6 & 93.5 & 10238.3 & 161.6 \\
\hline $\mathrm{F} 1+\mathrm{F} 2$ & 93.5 & 4095.3 & 292.7 & 98.9 & 6794.4 & 144.4 & 93.0 & 603.5 & 340.3 & 90.4 & 6978.9 & 203.5 & 97.5 & 8277.8 & 353.5 & 96.8 & 10793.2 & 175.8 \\
\hline \multirow[t]{2}{*}{ Mean } & 67.1 & 2723.10 & 161.2 & 73.3 & 4902.7 & 76.4 & 65.7 & \begin{tabular}{|l|}
2897.1 \\
\end{tabular} & 176.8 & 63.4 & 4746.7 & 106.4 & 72.13 & \begin{tabular}{|l|}
5551.7 \\
\end{tabular} & 204.2 & 70.7 & 7531.4 & 92.5 \\
\hline & \multicolumn{18}{|c|}{ Manganese (Mn) } \\
\hline Control & 47.3 & 1229.8 & 0.0 & 52.8 & 3115.2 & 0.0 & 46.5 & 1255.5 & 0.0 & 45.1 & 2841.3 & 0.0 & 51.5 & 2008.5 & 0.0 & 50.1 & 4308.6 & 0.0 \\
\hline $\mathbf{F} 1$ & 48.9 & 2117.4 & 72.2 & 54.6 & 3740.1 & 20.1 & 47.9 & 2203.4 & 73.6 & 46.2 & 3552.8 & 24.9 & 53.5 & 4504.7 & 124.3 & 51.8 & 5698.0 & 32.2 \\
\hline F2 & 98.9 & 4203.3 & 241.8 & 106.1 & 7225.4 & 131.9 & 96.5 & 4342.5 & 246.6 & 93.4 & 7145.1 & 151.3 & 104.5 & 8757.1 & 336.01 & 101.2 & 11081.4 & 157.0 \\
\hline $\mathrm{F} 1+\mathrm{F} 2$ & 100.4 & 4397.5 & 99.7 & 109.4 & 7515.8 & 141.2 & 98.7 & 4885.7 & 289.1 & 96.5 & 7449.8 & 162.2 & 107.8 & 9152.2 & 355.81 & 104.4 & 11640.6 & 170.0 \\
\hline \multirow[t]{2}{*}{ Mean } & 73.9 & 2987.0 & 103.4 & 80.7 & 5399.1 & 73.3 & 72.4 & 3171.8 & 152.3 & 70.3 & 5247.3 & 84.6 & 79.3 & 6105.6 & 204.0 & 76.9 & 8182.2 & 89.8 \\
\hline & \multicolumn{18}{|c|}{ Zinc ( Zn ) } \\
\hline Control & 27.9 & 725.2 & 0.0 & 31.8 & \begin{tabular}{|l|}
1876.2 \\
\end{tabular} & 0.0 & 27.5 & 742.5 & 0.0 & 26.6 & 1675.8 & 0.0 & 31.3 & 1220.7 & 0.03 & 30.32 & 2607.5 & 0.0 \\
\hline F1 & 27.9 & 1208.1 & 66.7 & 33.8 & 2315.3 & 23.48 & 28.5 & 1311.0 & 74.3 & 27.15 & 2087.8 & 24.6 & 31.1 & 2618.6 & 114.9 & 30.8 & 3388.0 & 29.7 \\
\hline F2 & 45.18 & 1920.2 & 164.1 & 51.2 & 3486.7 & 5.7 & 44.2 & 1989.0 & 168.4 & 44.5 & 3404.3 & 103.2 & 49.8 & 4173.2 & 242.1 & 51.3 & 5617.4 & 115.212.1 \\
\hline $\mathrm{F} 1+\mathrm{F} 2$ & 50.7 & 2220.7 & 205.2 & 54.4 & 3737.3 & 99.0 & 49.4 & 2445.3 & 229.0 & 47.2 & 3643.8 & 117.3 & 55.1 & 4678.0 & 283.8 & 52.9 & 5898.4 & \\
\hline Mean & 37.9 & 1518.6 & & 42.8 & 2853.9 & & 37.4 & 1621.9 & & 36.4 & 2702.9 & & 41.8 & 3172.6 & & 41.3 & 4377.8 & \\
\hline
\end{tabular}


studied treatments were associated by an increases of barley plants (shoots and roots ) content ( $\mathrm{mg} / \mathrm{kg}$ and $\mathrm{mg} / \mathrm{pot}$ ) of $\mathrm{Fe}$, $\mathrm{Mn}$ and $\mathrm{Zn}$ at ages either of $\mathbf{4 2}$ or $\mathbf{7 0}$ days. According to the effect of foliar application (F1) and (F2) on barley plants ( shoots and roots) content ( $\mathrm{mg} / \mathrm{kg}$ and $\mathrm{mg} /$ pot ) of $\mathrm{Fe}, \mathrm{Mn}$ and $\mathrm{Zn}$, these treatments take the order F1 + F2 > F2 > F1 > control. This order was found with individual treatments of foliar applications and its combination with FYM at 42 and 70 days old of sowing . This trend is in harmony with the chemical composition of the sprayed solution and its effect on plant growth . These results are similar to those of Abdalla et al. (1992) ; Zakaria (2017) and El-Sanat (2018). Individual applications of FYM also resulted in an increase of barley plants ( roots and shoots ) content ( $\mathrm{mg} / \mathrm{kg}$ and $\mathrm{mg} /$ pot ) of $\mathrm{Fe}, \mathrm{Mn}$ and $\mathrm{Zn}$ at 42 and 70 days old. These increases attributed to its content of the determined micronutrients and also to its effect on the availability of this nutrients in the soil

- Also FYM application were associated with a decrease of soil $\mathrm{pH}$ and its content of $\mathrm{CaCO}_{3}$ which play a major role on the availability of micronutrients pointed out by Elgezery (2016 ) and Abou Hussien et al (2017). The increases effect of FYM and other organic manure on plant growth and its content of micronutrients mentioned before that by Emam ( 2011) ; Elgezery (2016) and El-Sanat (2018).

The presented data in Table 6 show RC (\%) values of $\mathrm{Fe}, \mathrm{Mn}$ and $\mathrm{Zn}$ uptake by both roots and shoots of barley plants at 42 and 70 days of sowing as affected by foliar applications of F1 , F2 and $\mathrm{F} 1+\mathrm{F} 2$ alone and in combination with FYM compared with the control treatment. All RC (\%) values of $\mathrm{Fe}, \mathrm{Mn}$ and $\mathrm{Zn}$ uptake by barley plants ( roots and shoots ) were positive ,where the high positive values of $\mathrm{RC}$ were found in the plants sprayed by $F 1+F 2$ in combination with FYM followed by those found with plants treated with FYM and sprayed by $F 2$ together. These findings means that, with irrigation using saline water the foliar applications of $\mathrm{Fe}, \mathrm{Mn}$ and $\mathrm{Zn}$ and $\mathrm{Si}$ individually and in combination with FYM may be decreased the harmful effect of salinity stress .

\section{-Barley Plants Content of Silicon (Si) .}

Data in Table 7 show barley plants (shoots and roots) $\mathrm{Si}$ concentration $(\mathrm{mg} / \mathrm{kg})$ and uptake (mg/pot) at 42 and 70 days old in sandy soil affected by foliar applications of F1 and F2 individually and combination with FYM. There are an increase of barley plants (shoots and roots ) content ( $\mathrm{mg} / \mathrm{kg}$ and $\mathrm{mg} / \mathrm{pot}$ ) of $\mathrm{Si}$ in plants sprayed by F1, F2 and F1+ F2 alone and in combination with FYM compared with the control. These increases varied widely from treatment to another and also from growth period to another. The highest contents $(\mathrm{mg} / \mathrm{kg}$ and $\mathrm{mg} /$ pot ) of $\mathrm{Si}$ were found in the plants treated by $\mathrm{F} 1+\mathrm{F} 2+\mathrm{FYM}$ at both ages 42 and 70 days followed by these found in the plants treated by F1 + FYM. This order was found with both roots and shoots. Also individual application of FYM were associated by an increase of barley plants content of $\mathrm{Si}$. The increase effect of the studied treatment on $\mathrm{Si}$ uptake by roots and shoots of barley plants at $\mathbf{4 2}$ and $\mathbf{7 0}$ days old may cleared from RC (\%) calculated for Si uptake affected by the studied treatments compared with the control as shown in Table 7. This Table show that all RC (\%) values of Si uptake by roots and shoots of barley plants at 42 and 70 days old were positive. The high RC (\%) values of Si uptake were found in the plants sprayed by $F 1+F 2$ in combination with FYM. These finding are in harmony with 
Table 7: Effect of the studied treatments on Si concentration $(\mathrm{mg} / \mathrm{kg})$ and uptake $(\mathrm{mg} / \mathrm{pot})$ of barley plants ( roots and shoots) and relative changes "RC"(\%) of its uptake in sandy soil irrigated by saline water .

\begin{tabular}{|c|c|c|c|c|c|c|c|c|c|c|c|c|c|c|c|c|c|c|}
\hline \multirow{5}{*}{ 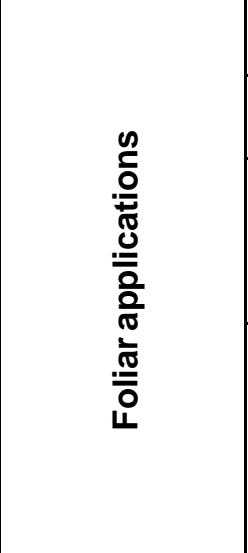 } & \multicolumn{18}{|c|}{ Growth periods ( days) } \\
\hline & \multicolumn{6}{|c|}{42 days } & \multicolumn{12}{|c|}{70 days } \\
\hline & \multirow{2}{*}{\multicolumn{2}{|c|}{$\begin{array}{l}\text { Without FYM } \\
\text { application }\end{array}$}} & \multirow{3}{*}{ 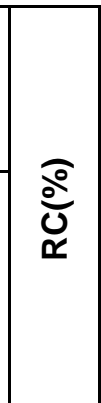 } & \multirow{2}{*}{\multicolumn{2}{|c|}{$\begin{array}{l}\text { With FYM } \\
\text { application }\end{array}$}} & \multirow{3}{*}{ ণ্ণ } & \multicolumn{5}{|c|}{$\begin{array}{c}\text { Without FYM } \\
\text { Application }\end{array}$} & & \multicolumn{6}{|c|}{$\begin{array}{c}\text { With FYM } \\
\text { application }\end{array}$} \\
\hline & & & & & & & \multicolumn{2}{|c|}{ Roots } & \multirow[b]{2}{*}{ ণ্ণ } & \multicolumn{2}{|c|}{ Shoots } & \multirow[b]{2}{*}{ 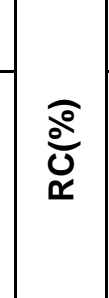 } & \multicolumn{2}{|c|}{ Roots } & \multirow[b]{2}{*}{ 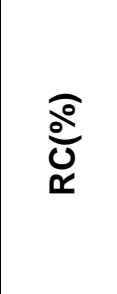 } & \multicolumn{2}{|c|}{ Shoots } & \multirow[b]{2}{*}{$\frac{\widehat{o}}{\stackrel{0}{0}}$} \\
\hline & 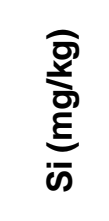 & 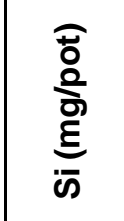 & & 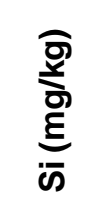 & $\begin{array}{l}\overline{0} \\
\text { ò } \\
\text { है } \\
\bar{\sigma}\end{array}$ & & $\begin{array}{l}\text { के } \\
\text { ছे } \\
\text { ह } \\
\bar{\omega}\end{array}$ & $\begin{array}{l}\overline{0} \\
\text { ò } \\
\text { है } \\
\bar{\sigma}\end{array}$ & & 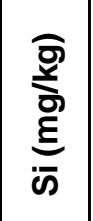 & 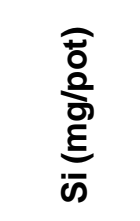 & & 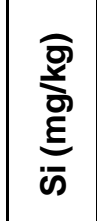 & 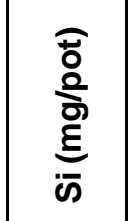 & & 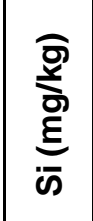 & $\begin{array}{l}\text { के } \\
\frac{\circ}{\circ} \\
\frac{\xi}{\omega}\end{array}$ & \\
\hline Control & 20.2 & 525.2 & 0.0 & 22.7 & 1339.3 & 0.0 & 19.8 & 534.6 & 0.0 & 19.1 & 1203.3 & 0.0 & 22.2 & 865.8 & 0.0 & 21.5 & 1849.0 & 0.0 \\
\hline $\mathrm{F} 1(\mathrm{~K}+\mathrm{SI})$ & 38.5 & 1667.1 & 246.1 & 46.5 & 3185.3 & 142.4 & 35.2 & 1619.2 & 270.4 & 29.5 & 2268.6 & 140.6 & 46.9 & 3949.0 & 362.9 & 46.2 & 5082.0 & 175.7 \\
\hline $\mathrm{F} 2(\mathrm{Fe}+\mathrm{Zn}+\mathrm{Mn})$ & 21.8 & 926.5 & 217.4 & 34.6 & $2356.3 \mid 1$ & 138.4 & 20.5 & 922.5 & 199.9 & 20.2 & 1545.5 & 88.5 & 27.3 & 2287.7 & 357.6 & 27.0 & 2956.5 & 170.4 \\
\hline $\mathrm{F} 1+\mathrm{F} 2$ & 41.5 & 1817.7 & 76.3 & 47.2 & 3242.6 & 76.3 & 39.9 & 1975.1 & 73.4 & 37.5 & 2895.0 & 28.1 & 47.1 & 3998.8 & 165.0 & 46.5 & 5184.8 & 58.1 \\
\hline Mean & 30.5 & 1234.1 & & 37.8 & 2530.9 & & 28.9 & 1262.8 & & 26.6 & 1978.0 & & 35.9 & 2775.3 & & 35.3 & $\mid 3768.1$ & \\
\hline
\end{tabular}


the chemical composition of sprayed solutions and their effect on plant growth and soil properties. These results are in agreement with those obtained by Shu and Liu. (2001); Richmond and Sussman (2003); Liang et al. (2003) and Zhu et al. (2004).

\section{REFERENCES}

Abdalla, F. E., Z. M. Mobarak and A. A. EISayed (1992). Effect of micronutrients foliar application on uptake of macronutrients by wheat and fababean. Afr. J. Agric. Sci.,19 (1): 181-192.

Abou Hussien, E. A., W. M. Nada and M. Kh. Elgezery (2017). Evaluation efficiency of sulphur fertilizer in calcareous soil amended by compost. Minufia J. of Soil Science., 2 (February): $59-72$.

Badran, N. M., M. E. A. Khalil and M. A. A. El-Emam (2000). Availability of N, P and $K$ in sandy and clayey soils as affected by the addition of organic materials. Egypt. J. Soil Sci., 40: 265283.

Britez, R.M., T. Watanabe, S. Jansen, C.B. Reissmann and M. Osaki (2002). The relationship between aluminum and silicon accumulation in leaves of faramea marginata (Rubiaceae). New Phytol. 156: 437-444.

Chapman, H.D. and P.F. Pratt (1961). Methods of Analysis For Soils, Plants and Water. Division of Agricultural Sciences, California , USA.

Costat 6.311, Copyright (C) (1988-2005) Cohort software 798 Lighthouse Are, PMB 320, Monterey, CA, 93940, USA Email: info@ Cohort. Com. http://www.cohort.com.

Cottenie, A., M. Verloo, L. Kiekens, G. Velghe and R. Gamerlynck (1982). Chemical Analysis of Plant and Soils. Laboratory of Analytical and Agro chemistry, State Univ. Ghent., Belginum.
Dagmar, D., H. Simone, B. Wolfgang, F. Rüdiger, E. Bäucker, G. Rühle, W. Otto and M. Günter (2003). Silica accumulation in triticum aestivum $\mathrm{L}$; and dactylis glomerata L., Analytical and Bioanalytical Chemistry, 376 (3): 399-404.

Elgezery, M. Kh. (2016) . Effect of organic addition on efficiency of sulphar fertilization. M. Sc. Thesis Fac. of Agric., Menoufia Univ., Egypt.

El-Sanat, G. M.A. (2018). Impact of subsoiling, organic manure and nitrogen sources on some soil properties and sugar beet productivity. Menoufia J. of Soil Science. 3 (February) : 1-16.

Emam, A. A. E. (2011). Effect of irrigation water salinity on organic matter in soil and status of some nutrients. M.Sc. Thesis, Fac. of Agric. Menoufia Univ, Egypt.

Epstein, E. (1999). Silicon. Ann. Rev. Plant Physiol. Plant Mol. Biol., 50: 641664.

Gillman, J.H., D.C. Zlesak and Smith,J.A. (2003). Applications of potassium silicate decrease black spot infection in Rosa hybrida $>$ Meipelta $=$ (Fuschia Meidland). Hort. Science, 38:11441147.

Gohar, H. M. (2011). Effect of some plant residues on soil properties and plant growth in newly reclaimed soils. $M$. Sc. Thesis. Fac. of Agric. Menoufia Univ., Egypt.

Klute, A. (1986). Methods of Soil Analysis. American Society of Agron., Inc. Soil Sci. Soc. of Amer., Inc. Madison Wisconsin, USA, $2^{\text {nd }}$ Edition.

Korndörfer, G.H. and Lepsch, I. (2001). Effect of silicon on plant growth and crop yield. In: Silicon in Agriculture: Studies in Plant Science, 8: 115-131.

Liang, Y.C., Q. Chen, W. H. Zhang and R. $X$. Ding (2003). Exogenous silicon (Si) increase antioxidant enzyme activity and reduces lipid peroxidation in 
roots of salt-stressed barley (Hordeum vulgare L.). Journal of Plant Physiology, 160: 1157-1164.

Marschner, H. (1995). Mineral Nutrition of Higher Plants. $2^{\text {nd }}$ Ed. Academic Press, London. Mitani, N; J.F. Ma and

T. Iwashita 2005. Identification of the Silicon Form in Xylem Sap of Rice.

Marschner, H. (1998). Mineral Nutrition of Higher Plants. Academic Press, Harcount Brace Janovisch Publishers.

Mitani, N., J.F. Ma and T. Iwashita (2005). Identification of the silicon form in xylem sap of rice (Oryza sativa L.). Plant Cell Physiol., 46(2): 279-283.

Page, A. L., D. E. Baker, Roscoe, T. R. Ellis, D. R. Keeney, R. H. Miller and J. D. Rhoades (1982). Methods of Soil Analysis. Part 2. Chemical and Micro Biological Properties. Second Edition. Amer. Soc. Agron, Madison, Wise. U.S.A.

Qadir, M., A. Tubeileh, J. Akhtar, A. Larbi, P.S. Minhas and M.A. Khan (2008). Productivity enhancement of salt affected environments through crop diversification. Land Degradation and Development 19: 429-453 Copyright 2008 John Wiley and Sons., Ltd.

Rehm, G. and S. Albert (2006). Micronutrients and production of hard red spring wheat. Minnesota Crop News. p: 1-3.

Richmond, K. E. and M. Sussman (2003). Got silicon? The non-essential benefical plant nutrient. Curr Opin Plant Biol., 6:268-72.
Rodrigues, F.Á., D.J. McNally, L.E. Datnoff, J. B. Jones, C. Labbe, N. Benhamou, J.G. Menzies and R. R. Bélanger (2004). Silicon enhances the accumulation of diterpenoid phytoalexins in rice: A potential mechanism for blast resistance. Phytopathology, 94: 177-183.

Shu, L. Z. and Y. H. Liu (2001). Effects of silicon on growth of maize seedlings under salt stress. Agro Environmental Protection, 20: 38-40.

Voogt, W. and C. Sonnenfeld (2001). Silicon in Horticultural Crops Grown in Soilless Culture. In: Silicon in Agriculture: Studies in Plant Science, 8. (Eds.): L.E. Datnoff, G.H. Snyder and G.H. Korndorfer. Elsevier Science, Amsterdam, The Netherlands. 115-131 pp.

Walia, H., C. Wilson, A. Wahid, P. Condamine, $X$. Cui and $T$. Close (2006). Expression analysis of barley (Hordeum vulgare L.) during salinity stress. Functional and Integrative Genomics. 6:143-156.

Zakaria, S. M. (2017). Effect of P-fertilizer and micronutrients ( $\mathrm{Fe}$ and Mo ) on seeds yield of soybean and its quality under sandy soil condition. Menoufia .J. of Soil Science ., 2 ( August) : 211225.

Zhu, Z. G., G. Q. Wei, J. Li, Q. Q. Qian and J. Q. Yu (2004). Silicon alleviates salt stress and increases antioxidant enzymes activity in leaves of saltstressed cucumber (Cucumis sativus L.). Plant Science., 167: 527-533. 
